\title{
Absorptive Capacity and the Internationalization Process of an Emerging Multinational
}

\author{
Graciella Martignago ${ }^{1}$, Silvio Antônio Ferraz Cário $^{2}$, Graziela Dias Alperstedt ${ }^{3}$ \\ Universidade do Sul de Santa Catarina (UNISUL) - graciellamartignago@gmail.com \\ Universidade Federal de Santa Catarina (UFSC) - fecario@yahoo.com.br \\ Universidade do Estado de Santa Catarina (UDESC) - gradial@gmail.com
}

\section{KEYWORDS}

Internationalization;

Emerging multinational;

Absorptive Capacity.

Received 11.04.2018

Revised 28.06.2018

Accepted 04.09.2018

ISSN 1980-4431

Double blind review

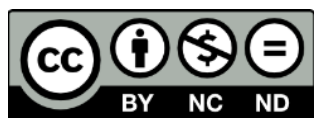

\section{ABSTRACT}

Knowledge is at the core of the process models of internationalization, although the impact absorptive capacity has on the internationalization is still unclear. Based on an evolutionary approach to international expansion and learning by a firm, the purpose of this study is to describe the role of absorptive capacity (AC) for the internationalization process of emerging multinational companies. A qualitative study, descriptive and longitudinal, was conducted based on a case study of the biggest cement company of South America. Our findings identified the previous knowledge about internationalization and the new knowledge that was acquired and assimilated on a needbasis case as key factors of international competition. This study showed that even a mature company, leader in its home market, with experience in competition with the main international players, needed to acquire new knowledge about internationalization. The assimilation of knowledge was hampered by the prior knowledge structure and new routines were created before the external direct investment materialized. After the acquisition in the foreign market, the adaptation of routines created in the domestic market was developed. We identify that there are relationships among the elements of absorptive capacity (acquisition, assimilation, transformation, exploitation) and that these affect the internationalization process of emerging market firms.

\section{PALAVRAS-CHAVE}

Internacionalização;

Multinacional emergente; Capacidade absortiva.

\section{RESUMO}

O conhecimento está no cerne dos modelos de processo de internacionalização, embora o impacto da capacidade de absorção na internacionalização ainda não esteja clara. Com base em uma abordagem evolutiva para a expansão internacional e aprendizagem por uma empresa, o objetivo deste estudo é descrever o papel da capacidade de absorção (AC) para o processo de internacionalização de empresas multinacionais emergentes. Um estudo qualitativo, descritivo e longitudinal, foi conduzido com base em um estudo de caso da maior empresa de cimento da América do Sul. Nossos resultados identificaram o conhecimento prévio sobre internacionalização e o novo conhecimento que foi adquirido e assimilado em um caso de necessidade como fatores chave para a competição internacional. Este estudo mostrou que mesmo uma empresa madura, líder em seu mercado doméstico, com experiência em concorrência com os principais players internacionais, precisava adquirir novos conhecimentos sobre internacionalização. A assimilação do conhecimento foi dificultada pela estrutura de conhecimento anterior e novas rotinas foram criadas antes que o investimento direto externo se materializasse. Após a aquisição no mercado externo, foi desenvolvida a adequação das rotinas criadas no mercado interno. Identificamos que existem relações entre os elementos de capacidade absortiva (aquisição, assimilação, transformação, exploração) e que estas afetam o processo de internacionalização das firmas de mercados emergentes. 


\section{Introduction}

Studies about emerging multinationals companies, as "latecomers or latemovers", began in the 1980s (Lall, 1983; Wells, 1983; Mathews; Cho, 1999; Wilkins, 2010). With the greater relevance of these investments to the global economy, since the decade of 2000, there has been rapid growth in the literature about this phenomenon.

Various international journals have dedicated special editions to this theme and many of them have focused on the creation of capabilities and question "if" and "how" the internationalization of emerging multinationals differs from the internationalization of traditional multinationals from developed countries (Mathews, 2006; Dunning et al, 2008; Luo \& Tung, 2007; 2018, Guillén \& Garcia-Canal, 2009; Ramamurti, 2009, 2012; Becker-Ritterspach \& Gert Bruche, 2012; Cuervo-Cazurra, 2012; Meyer \& Peng, 2016; Hernandez \& Guillén, 2018). Nevertheless, little is still known about the internationalization process of emerging companies (Cuervo-Cazurra \& Genc, 2008; Madhok \& Keyhani, 2012). The core question asked by Buckley et al (2007), whether the internationalization of emerging multinationals challenges what we know from developed multinational enterprises, continues to be debated (Hernandez \& Guillén, 2018).

There are still many unanswered questions and it remains an issue that requires greater attention from scholars (Ramamurti, 2009; Wells, 2009; Wilkins, 2010; Cuervo-Cazurra, 2008; 2016), considering the unknown quality of the consequences of the process, to all the parties involved. Particularly needing recognition from Brazilian academics, who face a phenomenon still in development.

Brazilian multinationals are part of a group of "late globalizers", which imposes a series of challenges on these companies, such as combatting competition in the domestic market, the need to be technologically up-to-date, have the best practices and to expand internationally. The firms that overcame these challenges did so by transforming their status as latemovers into a network of advantages, not only in other emerging economies, but also in developed countries (Fleury \& Fleury, 2011).

To understand how these companies have positioned themselves in the dynamic international market and became relevant global competitors from their base in these emerging countries requires the analysis of the absorptive capacity (AC) (Cohen, Levinthal, 1990) in the internationalization of these companies, given that knowledge is an essential resource for internationalization (Johanson \& Valhne, 1977; Casillas et al, 2009; Teece, 2007; 2014). As a dynamic capability, absorptive capacity allows firms to continuously upgrade their resources and gain advantage, what is critical to emerging firms that operate abroad (Bilgili et al, 2016). Absorptive Capacity contributes to International Business (IB) as a major determinant of knowledge process in the multinational context and the IB scholars confirm the significance of absorptive capacity in several contexts (Apriliyanti \& Alon, 2017). However, there are few studies of absorptive capability in the context of emerging market firms (Wu \& Voss, 2015; Cuervo-Cazurra \& Rui, 2017; Garrido et al 2017). The research questions about dynamic capability of AC must address the relationship between organizational mechanisms and the AC process, as well as how a firm builds different organizational mechanisms to increase AC (Apriliyanti \& Alon, 2017).

From an evolutionary approach of international expansion and firm learning, this paper assumes that emerging multinationals are able to achieve and sustain their global competitive position even in the face of the firm's limited resources and country-specific advantages (Lessard \& Lucea, 2009) and aims to describe the role of absorptive capacity for the internationalization process of emerging multinational companies. Therefore, this study contributes to provide a better understanding of the internationalization process of emerging firms by providing depth to the understanding of the knowledge prior internationalization, the new knowledge acquired for internalization and the assimilation, transformation and exploitation of knowledge for internationalization.

The decision to operate in the international market requires the company to learn, acquire and absorb knowledge to achieve this strategy. If, and to what extent, new knowledge is integrated into the capabilities generated throughout the company's historical development process, will determine the position of the emerging multinational in relation to its competitors (Casillas et al, 2009).

For the development of this learning process, 
companies start from current capacities and generate new capacities based on the development of the international activities; therefore, the internationalization process is a dynamic of learning and capacity development. New knowledge is absorbed, shared, and built over time through organizational routines (Nelson \&Winter 1982, Cohen \& Levinthal, 1990).

The internationalization process begins before the first action abroad, when there is recognition that the international market is a source of opportunities for growth and increase profitability, and develops as the company seeks and acquires new knowledge, forming new routines and procedures (Casillas et al, 2009).

But this process does not occur dissociated from an external and internal context of the company, and therefore, is dependent on a path, a history developed by the organization over the years, which makes relevant the realization of the historical recovery of the company in its market source.

This research has as its objective the study of the company Votorantim Cimentos, participant in one of the largest conglomerates in Brazil, leader in its segment and one of the largest players in the world in the cement industry, with 31,8 million tons of cement produced per year and more than 11 thousand employees. The company is 100 years old (Votorantim, 2017).

Votorantim's internationalization process is a revelatory case not only for its relevance to the brazilian and world economy, but also due to the inherent characteristics of its internationalization process: a traditional competitor in the home market, it loses its position in the world market in relation to competitors from other developing countries, and enters the foreign market as a late mover. One of the great gaps in the debates in international business (Buckley et al, 2017) remains the process of internalization of "latemovers," like Votorantim, that learned how to operate in new foreign markets based on the knowledge acquired in the home market. Votorantim is family owned, closed capital company, subsequently its internationalization process was little investigated (Santos, 2008; Furquim \& Meireles, 2012; Colantuono \& Pinho, 2012). This research delves mainly into the perspective of direct participants in the decision making for internationalization, introducing unique data for analysis.

$$
\text { Studying the role of AC for }
$$

internationalization has great relevance for companies from emerging countries and for the international business academy, which seek theoretical explanations for this new phenomenon. But above all, this new study has great pertinence for Brazilian companies, which are born in one of the most closed countries in the world, which, despite being among the ten largest global economies, accounts for $1 \%$ of world trade and $0.4 \%$ of the outward FDI issued in the world (UnctadStat, 2016).

This theme gains greater importance for contemporaneity, originality and the generation of knowledge shared with other companies of the country that aim to expand their activities abroad. The study of the process will produce knowledge about the "how to," so crucial to the practice of managers (Pettigrew, 2012) and for developing countries, which aim to expand the international insertion of their companies, still little exposed to global competition (Coutinho et al, 2008). This theme is also fundamental for public policy makers in order to facilitate internationalization.

This research will have the company as the basic unit of analysis. It is based on the assumption that firms constitute open systems, in permanent coevolution, in an iterative process between environment and organization in the development of their strategies (Chandler, 1962; Child, 1972; Nelson \& Winter, 1982). The environment, in this case, acts as a constraint to management decisions, but there is room for active decisions, in which it is possible for organizational actors to determine the strategies that will ultimately define the organization's directions.

Internationalization is understood as a strategic process (Melin, 1992) and as such, it must be analyzed from a contextualist and procedural approach, as proposed by Pettigrew (1987). The relationships and interdependencies between the organizational levels belonging to the internal and external context of the organization, from a sequence of actions and events in a historical way, will be examined.

This study addresses two major trends in internationalization research: the increasing interest in 'processes' (sequence of events over time) and the focus on 'practices' (micro level actions contextually), only achievable from longitudinal studies (Blazejewski, 2011; Pettigrew, 2012).

Decisions are made within an internal

Revista de Negócios, v. 23, n. 1, p. 7-30, January, 2018. 
political context, and organizational actors, when defining reality according to their antecedents, values and mental models, can perceive the same phenomenon in a differentiated way, which characterizes the heterogeneity of companies (Child \& Smith, 1987; Nadkarni, 2011). Therefore, for the study of business strategies not only objective conditions are important, but also the perception of social actors that create the cognitive arena (Child \& Smith, 1987).

Furthermore, to internationalize, companies need to develop capabilities and obtain resources (Penrose 1959; Barney, 1991). Understanding the process of internationalization requires comprehending the process through which firms renew their competencies in response to changes in the competitive environment. Internationalization implies a reconfiguration of activities, or an incorporation of new resources and especially new routines and processes. Subsequently, the notion of "knowledge generation" becomes relevant for the adaptation of companies to a new environment, at the same time as a unique process.

It is recognized that the idiosyncratic local conditions of emerging markets are initial sources of international competitive advantage and that the development of new capabilities during the internationalization process is crucial to the sustainability of the multinational enterprise and that these two groups of capabilities, in the country of origin as well as those derived from international operations, need to be continually evaluated, adapted, integrated and disseminated through the organization (Lessard \& Lucea, 2009).

In the next section, we present the theoretical background of the research. We then describe our methodology and present the results. Finally, we discuss our results and present conclusions and managerial implications.

\section{Theoretical Framework}

For the development of dynamic capability, it is essential to have the ability to integrate and to combine assets such as knowledge. The creation of knowledge, its sharing and the integrating procedures are critical for the performance of the firm and a key micro foundation for the dynamic capabilities (Teece, 2007).

An important dynamic capability of the organization is its ability to absorb knowledge.
Conceptualized first by Cohen and Levinthal (1990), these authors define AC as the "ability of the firm to identify, assimilate and explore knowledge of the outside environment" (p.569). This definition was elaborated on by Zahra and George (2002) who consider it as "a group of organizational routines and processes by which firms acquire, assimilate, transform and explore knowledge" (p. 186). The concept was later operationalized by various studies (Tsai, 2001; Jansen, Van Den Bosch \& Volberda, 2005; Lane et al (2006); Chen et al, 2009; Camisón \& Fóres, 2010; Flatten et al., 2011; Jimenez-Barrionuevo et al, 2011; Buckley \& Park, 2014), despite its abstract, intangible essence that is difficult to measure (Szulanski, 1996).

These capacities (the ability to acquire, assimilate, transform and explore) represent four dimensions of the capability for absorption, which is a dynamic capability that influences the ability of the firm to create and employ the knowledge needed to construct other organizational capabilities. Although Zahra and George's (2002) model has provided a better understanding of the construct, at the same time, its separation into four dimensions has been criticized (Lane et al, 2006; Todorova \& Durisin, 2007).

Todorova and Durisin (2007) affirm that the recognition and understanding of the outside knowledge value, originally defended by Cohen and Levinthal (1990), should be introduced as a component prior to acquisition. In this sense, the authors also emphasize that the relationship established between assimilation and transformation is not suitable. They thus argue that transformation should be an alternative to assimilation and not a step after it.

At the same time in which the absorption capability involves the need to acquire knowledge of the outside environment, it also focuses on the internal learning processes based on past experience and current actions (EasterbySmith et al, 2008). Depending on the source of knowledge and on the previously held knowledge, AC is conditioned by the regime of appropriability (Cohen \& Levinthal, 1990).

The model proposed by Todorova and Durisin (2007) captures the dynamic aspect of the phenomenon, which is in keeping with the concept of the dynamic capability that involves organizational change and with an evolutionary approach, and therefore, can constitute a basis for

Revista de Negócios, v. 23, n. 1, p. 7-30, January, 2018. 
the development of a framework for the role of absorptive capability in the internationalization process.

It is admitted that the first component of the absorption capability consists in the recognition of the value of outside knowledge (Cohen \& Levinthal, 1990). Corroborating Teece (2014), Nonaka and Takeuchi (1997) emphasize that the most critical elements of the company strategy are the conceptualization of a vision about the type of knowledge that must be developed and the operationalization of this knowledge in a management system of implementation. Organizational intent provides the most important criterion for judging the veracity of a given knowledge. If it were not for the intention, it would not be possible to judge the value of the information or the knowledge perceived or created. At the organizational level, intention is often expressed by organizational patterns or visions that can serve to assess and justify the knowledge created. Intent is necessarily charged with value (Nonaka \&Takeuchi, 1997, p.84). The role of top management should therefore be to formulate an organizational intent and to propose such an intention to employees as a way of guiding individuals and promoting a collective commitment (Takeuchi, 1997). In the specific case of the organization that intends to internationalize, it will seek knowledge about the foreign market, the institutional aspects of the exterior and internationalization itself, which is related to the experience that the company had on international activities in different countries (Erickson et al, 1997). The knowledge about internationalization is knowledge based on the company's experience in working its resources and skills to operate in the international market. It is an accumulated learning over time (Eriksson et al, 1997; Argote, 1999), derived from learningby-doing and allows the firm to develop new routines. Throughout the experience, it can also develop learning-by-interacting, as it establishes relationships with other organizations (Zahra \& George, 2002; Nelson \& Winter, 2005).

The effort to acquire knowledge, according to Zahra and George (2002), has three attributes that can influence the absorptive capability: the intensity of the search, the speed and the direction. The higher the effort, the faster the firm will build the necessary capabilities, but the inherent limitations of the process, such as learning curves, can limit speed. The direction refers to the paths that the firm will adopt in order to obtain external knowledge. Past experience tends to define the search locus for new knowledge, that is, the firm searches for information where it has succeeded in the past, which may influence the development of future capabilities (Zahra \& George, 2002). According to Johanson and Vahlne (1997), the search for knowledge for internationalization tends to be greater in countries where psychic distance is lower.

As there is individual, organizational and interorganizational learning (Cohen \& Levinthal, 1990), information for new knowledge can come from both the individual and organizational levels and from the interorganizational level (Casillas et al, 2009). According to Cohen and Levinthal (1990), individuals are storehouses of knowledge. This knowledge is gained by general and professional experience in different organizational and social environments that they experience throughout life. It is knowledge based on experience, which depends on one's personal history and is fundamentally tacit in nature. It is the current tacit knowledge that allows individuals and organizations to create greater future tacit knowledge through various forms of knowledge conversion (Kim, 2005). In the specific case of internationalization, therefore, firms may choose to put on the management staff people with international experience in other companies as a way of acquiring knowledge and skills that will be used to develop the firm's internationalization process. As a fundamental aspect, at the individual level, the members of an organization must have autonomy, as a way of stimulating the creation of knowledge (Nonaka \& Takeuchi, 1997).

In addition to individual knowledge, collective knowledge can be generated by the communication and distribution of knowledge among management members and also through the accumulated experience of the organization through cumulative behaviour. The accumulation of decisions, actions and results creates a unique trajectory, path dependent path, developed over time (Eriksson et al 2000). According to Zahra and George (2002), the organizational memory, the depository of knowledge of the firm, is connected to experience. Absorption capability is, therefore, a path-dependent capacity,

Revista de Negócios, v. 23, n. 1, p. 7-30, January, 2018. 
influenced by past experiences that are internalized by organizational memory. As experience reflects past successes and failures, it influences how the firm acquires and assimilates knowledge, as well as the locus of future technological search (Zahra \& George, 2002).

Cohen and Levinthal (1990) also highlight the role played by the communication structure as well as the character and distribution of experience within the organization. The communication structure consists of the transfer of knowledge between the external environment and the organization, as well as between the subunits of the organization. Young firms, with simple and more flexible structures, have a fluid exchange of information and experience between the founders and between the founders and the new senior managers. In this type of situation, which presupposes that directors have varied international experience abroad, the exchange of tacit knowledge will be more likely among members of a young organization than of an older organization with more rigid structures and where communication channels are historically more formal (Casillas et al, 2009).

Once the new information is incorporated, firms are able to generate new collective knowledge through the accumulation of experience, first in the domestic market and then in foreign markets. Different factors related to the experience in the domestic market boost the firm's propensity to begin its internationalization, such as the size of the domestic market, the presence of foreign competitors, the presence of consumers and international suppliers, the growth rate of the local market, etc (Eriksson et al 2000).

Besides the individual and organizational level, the aspect of interorganizational relations for the acquisition of knowledge can not be neglected. The individuals that make up the organizations are not isolated entities, but form an organizational and social network that contributes to the generation of knowledge for the decision to move to the international market. Directors and firms belong to international networks - through their relationships with consumers, suppliers, consultants, associations etc. - and have access to information that is relevant to identifying opportunities abroad. The literature on networks suggests that individuals and organizations access information through interaction with other individuals and organizations (Casillas et al, 2009).

In these aspects, in which prior knowledge is relevant to the development of the capacity to internationalize, the process of internationalization is considered to start when the firm or organization recognizes that the international market is a source of growth opportunities or increased profitability, which occurs long before the first action abroad. When a company identifies an opportunity in an international market, it is unlikely that it has sufficient knowledge to make a decision about the commitment of resources to that market. The company will therefore seek new knowledge about the tastes and needs of new consumers, the size of the potential market, market entry, the nature of government institutions and competitors in that market etc (Johanson \& Vahlne, 2006).

The acquisition of international knowledge is an iterative process (Knight \& Liesch, 2002). The firm enters a continuous cycle of information search, translation and assimilation for internationalization. We look for existing information and evaluate whether the accumulated information is sufficient to go to the next stage (action). This first stage, according to Casillas et al (2009), corresponds to the concept of exploitation of March (1991), which is obtained through the learning process of variation, varied experimentation and action. Until this last point is reached, the firm will continue the search for information. The speed with which the firm will enter the new market is directly related to the time spent by the company to acquire and develop the knowledge needed for future launches. This is the time between the stage of exploration and exploitation (March, 1991). Two aspects affect the duration of this search process: the quantity and quality of previous knowledge and the nature of the information sources used by the company (Casillas et al., 2009). The key determinant of how long the process of pursuing the new knowledge will last is the level of prior knowledge available within the company. The firm will need two types of relevant knowledge: knowledge of the new geographic market and knowledge of certain processes related to growth management (Eriksson et al., 1997). The organization and management of business

Revista de Negócios, v. 23, n. 1, p. 7-30, January, 2018. 
activities related to internationalization may suffer significant influence from the experience in the domestic market. These companies that have experience in domestic acquisitions can use it in the search for possible business to acquire in the target country (Blomstermo et al, 2004).

To increase its knowledge base, the firm must have access to external and internal sources of information (Zahra, George, 2002). Internal information is gained through the organization itself - knowledge based on experience, acquired by individual managers and the organization through cumulative decisions. They are information obtained through participation in fairs, business trips and missions abroad, visits of different durations to potential markets etc (Casillas et al, 2009). External information is obtained through certain intermediaries that provide pre-developed information and coded information transferred by the company in response to specific demands. This information comes from organizations that aim to promote internationalization, both public and private, external consultants, sales agents, market researches, specialized journals (Casillas et al., 2009, Flatten et al, 2011). They also come from acquisition processes, purchase agreements, licensing and interorganizational relations, such as R\&D consortiums, alliances and joint ventures. The deeper and wider the firm's exposure to knowledge sources, the more likely it will be to create new knowledge (Zahra; George, 2002).

The greater the diversity of sources, the greater the influence of the acquisition and assimilation of the absorption capacity. But this is not a guarantee that the firm will have a higher level of absorptive capacity, especially when the knowledge sources have low complementarity with the firm's knowledge base (Zahra; George, 2002). The search for knowledge will be influenced by activation triggers (Winter, 2000). These are events that encourage or compel a firm to respond to internal and external stimuli. Internal triggers may be organizational crises, such as underperformance, or events that redefine firm strategy, such as mergers (Zahra \& George, 2002). Nonaka and Takeuchi (1997) denominate this phenomenon as creative chaos, in which tension is generated within the organization and the members focus attention on problem definition and crisis resolution. A crisis of competitiveness in the market and the implementation of a strategy to reverse the situation require investments in the acquisition of new tacit and explicit knowledge, such as the hiring of new employees. It is a way for companies to turn the crisis into an opportunity. This crisis can even be intentionally generated when top management evokes the feeling of crisis by proposing challenging goals (built crisis) or when an external agent, such as the state, imposes challenging goals for companies of a chosen industrial branch (imposed crisis) (Kim, 2005). In the case of the crisis built, it is the top management, with an entrepreneurial spirit, that introduces the crisis. This forces discontinuous learning, which articulates metaphors and symbols that guide the organization, and creates work teams that control the learning process throughout the organization. It also provides the resources to support learning activities to make the crisis creative, and which removes the various obstacles to the learning process (Kim, 2005). External triggers are events that can influence the future of the industry as radical innovations, changes in government policy, environmental turbulence (Zahra \& George, 2002; Volvo, Foss \& Lyles , 2010).

Assimilation refers to the processes and routines that allow the firm to analyse, process, interpret and understand the information obtained externally. This capability may not be developed for a number of reasons, such as the fact that the new information is outside the search zone, involves a heuristic understanding that differs from those used by the firm or is closely related to a particular unfamiliar context (Zahra \& George, 2002). The greater the effort made to assimilate the new knowledge, the more effective this knowledge will be (Cohen \& Levinthal, 1990), but there are strong inertial forces that reinforce the continuity of old patterns and, therefore, the knowledge coming from experience plays a fundamental role (Eriksson et al., 1997, 2000; Johanson \& Vahlne, 1977). As Kim (2005) explains, assimilation depends on the intensity of effort or commitment to new knowledge. It is not enough to expose individuals and companies to explicit knowledge, but there is a need for a conscious effort by individuals to internalize such knowledge, otherwise learning will not occur. The firm will continue its quest for

Revista de Negócios, v. 23, n. 1, p. 7-30, January, 2018. 
new knowledge until it feels it is ready for action (internationalization). This time will not come as management continues to regard the uncertainty as too high. The process of creating new knowledge is developed through an upward spiral that ends when organizational actors merge to accept a specific base knowledge, depending on the degree of quality and confidence of the new knowledge acquired, which consists of the justification process of Nonaka and Takeuchi (1997). The decision to launch a new country does not arise independently of prior knowledge or new knowledge acquired, but by a combination of the two. The ability to assimilate new knowledge depends on the existence of routines and procedures that allow this new information to be analysed, processed, interpreted and understood. In the same way, the company must have routines that allow to combine the previous knowledge with the new one (transformation).

The transformation dimension proposed by Zahra and George (2002) implies an ability to adjust both the new and the old knowledge chains. The ability of the company to guide the use of this knowledge in a specific international context depends on the quality of this adjustment (Casillas, et al, 2009). The transformation consists of the firm's ability to develop and refine the routines that combine existing knowledge with new knowledge. Absorption capacity also requires the company to be able to apply its new knowledge base through a chain of actions (Cohen \& Levinthal, 1990; Lane et al, 2006, Zahra \& George, 2002). But, as Todorova and Durisin (2007) point out, when the new information acquired fits the existing cognitive themes, the new idea is incorporated into the existing knowledge structure. Therefore, the structure of knowledge does not change and knowledge is assimilated. But alternatively, transformation occurs, that is, when new knowledge can not be assimilated because the cognitive structure of individuals must be transformed to adapt to new ideas. It is the firm's ability to recognize two groups of information and combine them. Knowledge has a cumulative nature and when new knowledge is not related to existing knowledge, the adoption of new knowledge is conditioned by unlearning. In the case of internationalization, companies in which this process occurs early in organizational life may be easier to operate abroad, since newer firms have learning advantages (Barkema, Vermeulen, 1998).

From the assimilation of the new knowledge, the management responsible for the strategy of the company will evaluate the new situation and, depending on the result, will make particular decisions in consideration to: (1) go forward or not go ahead; (2) your preferences for geographical markets; (3) the choice of how to launch the new market. The influence of the nature of the new knowledge and the type of international behaviour depends on two subjective factors: the first is the degree to which the new knowledge is compatible with the first; the second is the degree to which any lack of information needed to enter the new country is identified (Casillas et al, 2009). Taking into account these aspects, Casillas et al (2009) propose that the speed with which the company launches in a specific international market is positively related to the capacity of absorption of knowledge.

Cohen and Levinthal (1990) not only defended the idea that learning new knowledge depends on the existence of prior knowledge, but also that the motivation to learn depends on the results of the learning process itself. It is a question of self-reinforcing behaviour related to the innovative behaviour (Cohen \& Levinthal, 1990). Within the domain of internationalization, Casillas et al (2009) identify this cycle of reaffirmation through the degree to which the new knowledge is compatible with previous knowledge, allowing the company to develop new, coherent and more complete information. This compatibility depends on the degree to which the new information: (1) confirms initial expectations regarding the opportunity for international expansion; (2) adds new and noncontradictory information to prior information and (3) identifies in concrete terms what knowledge is retained - quantity, quality, and reliability - and what knowledge is missing. The ability to adjust prior knowledge to new knowledge is related to "current absorptive capacity", which reflects the company's ability to take advantage of the knowledge that has been absorbed (Zahra \& George, 2002). This lack of coherence between prior and new knowledge can grow from the failure to confirm the initial assumptions, the identification of risks, a reduction in the apparent attractiveness of the

Revista de Negócios, v. 23, n. 1, p. 7-30, January, 2018. 
opportunity, or the identification of a lack of readiness for internationalization (the need for resources the need for disproportionate changes in the organization, etc.) (Casillas et al, 2009). When Cohen and Levinthal (1990) relate the ability to absorb the new knowledge to the existence of prior knowledge, they are implicitly assuming that the new knowledge is coherent with the previously existing one and that a process of adjustment between the two occurs. This adjustment represents an integration of both the new knowledge and the previous one, which allows for a coherent structure of knowledge, retained by both individuals and the organization, to expand. Conversely, when new knowledge can not be coherently integrated with prior knowledge, the absorptive capacity is greatly reduced. In this situation, new knowledge is rejected or, individuals have to redesign the existing knowledge structure. Given this lack of adjustment, the company will put brakes on the initial intentions, giving the project of external expansion as complete or postponed. Therefore, the degree to which the new knowledge is compatible with previous knowledge is positively related to the speed with which a company enters the international market (Casillas et al, 2009). Companies that have a high level of knowledge will choose to use methods of launching with a high level of control over international operations (greenfield investments, acquisitions, etc.).When a company has international knowledge, but lack institutional knowledge about a certain country, this deficiency can be overcome by cooperation and trade agreements with local companies and institutions that provide this information (Eriksson et al, 2000). When a company does not clearly perceive what kind of knowledge it has or what kind of knowledge it is lacking, it will tend to better understand uncertainty and try to minimize risk as much as possible by entering countries that are physically or culturally closed or using methods they represent a low commitment of resources.

Finally, exploitation is the application of knowledge. They are the routines that allow the firm to refine, extend and increase the competencies or create new ones by incorporating the acquired knowledge and its transformation. Action is a source of learning through feedback. Specific entry actions in a new country represent the primary source of learning for a company that is internationalizing. This learning is mainly developed through the acquisition of knowledge based on the accumulation of international experience. This experience gives the company the ability to identify new business opportunities and reduces the level of uncertainty associated with the commitment in new international markets, as well as providing knowledge on how to manage international operations or knowledge about the internationalization process (Eriksson et al., 1997 , 2000). There is also learning about the market and institutional knowledge. In this sense, as the firm accumulates experience, this learning process tends to gain momentum as a result of the broad knowledge base and the development of certain dynamic abilities related to information search ability, absorption capacity, etc. (Casillas et al. , 2009). Studies have shown that the experience in making acquisitions (Vermeulen \& Barkama, 2001) and alliances (Kale, Dyer \& Singh, 2002) increase performance in the realization of new acquisitions and alliances, showing that the experience generates learning throughout history organizational structure. There is, therefore, an accumulation of capacities, such as cultural adaptability, receptivity to change (Sapienza et al, 2006).

Bingham and Eisenhardt (2011) analysed what firms learn from the explicit learning generated by the internationalization process, that is, what members of the company collectively articulate as a result of international experience. They concluded that learning goes far beyond routines. Through experience, patterns of action are formed that are repositories of lessons learned from experience. Routines and heuristics can be formed. Routines store organizational experience in a way that allows the organization to quickly transfer this experience to new situations. They are the repositories of organizational capacities (Nelson \& Winter, 2005; Zollo \& Winter, 2002). They allow coordinated action, but do not necessarily consist of an appropriate response to changes in the environment. Routines both preserve organizational memory and represent a source of endogenous change (Becker et al, 2005). While routines consist of detailed, almost automatic answers to particular problems, heuristics provide a common framework for a group of similar problems, but provide few details about specific solutions to problem

Revista de Negócios, v. 23, n. 1, p. 7-30, January, 2018. 
solving. Firms develop heuristics that are idiosyncratic and represent the particularity of the firm (Bingham \& Eisenhardt, 2011).

In addition to these aspects, we highlight the contingency factors that influence the absorption capacity. An important barrier stems from social integration mechanisms. The exploitation of knowledge requires the sharing of knowledge among the members of the firm as a way to promote mutual understanding and understanding of the new. However, structural, cognitive, behavioural, and political barriers can stifle this process of knowledge sharing. It is up to the organization, therefore, to create formal and informal mechanisms to facilitate the distribution of knowledge within the organization and among organizations (Camisón \& Fóres, 2010; Zahra \& George, 2002; Todorova \& Durisin, 2007). Not only is the ability to assimilate knowledge influenced by social interaction mechanisms, such as other components of absorptive capacity such as acquisition. The ability to identify external knowledge requires investing in social networks and social integration initiatives (Todorova \& Durisin, 2007).

Todorova and Durisin (2007), when modifying the model proposed by Zahra and George (2002), added the relations of power. According to the authors, the relations of power within the organization influence the exploitation of new knowledge through the process of allocation of resources. Therefore, even if the company has the necessary knowledge for internationalization, it is in the relations of power that the strategic choices reside and, in this respect, the strategic intentionality can not be disregarded.

The above review suggests that absorptive capability is a construct with elements (acquisition, assimilation, transformation and exploitation) that affect the internationalization process.

\section{Methodology}

The decision was made to conduct a qualitative and longitudinal study (Denzin \& Lincoln, 1994, p.23). A qualitative study adopts procedures that "are related with the meanings, not with the frequency of a phenomenon through its study in a certain social context (Marschan-
Peikkari \& Welch, 2004, p.6; Van Maanen, 1983) and a longitudinal study focuses on the process and permit to answer the "how question" that is concerned with describing and explaining the temporal sequence of events (Van de Ven \& Huber, 1990; Burgelman, 2011). The process analized the critical events that happened before the first company's entry in the international market until to turn one of the $10^{\text {th }}$ biggest cement company's in the world, with plants in 12 countries.

In addition to being descriptive, this study is interpretive and inductive because this allowed the interpretation of the data collected and favored interaction during the interviews (Miller \& Friesen, 1982; Taylor \& Bogdan, 1998).

Since the reality studied is complex and poorly known, it was decided to begin with questions of broad interest, as suggested by various authors (Miles \& Huberman, 1984; Eisenhardt, 1989). A "voluntary suspension of belief" was established, as Gioia et al (2012) call for, and only a theoretical structure with broad references was used, as indicated in Table 1.

Table 1. Main guiding categories of research and the authors of reference

\begin{tabular}{|c|c|c|c|}
\hline Category & Property & Dimension & Theoretical Base \\
\hline \multirow{3}{*}{$\begin{array}{l}\text { Absorpti- } \\
\text { ve } \\
\text { Capacity } \\
\text { of } \\
\text { Knowled- } \\
\text { ge to } \\
\text { Internatio- } \\
\text { nalization }\end{array}$} & $\begin{array}{l}\text { Knowledge } \\
\text { prior } \\
\text { Internationali- } \\
\text { zation }\end{array}$ & $\begin{array}{l}\text { Individual } \\
\text { knowledge; } \\
\text { Organizational } \\
\text { knowledge; } \\
\text { Interorganiza- } \\
\text { tional } \\
\text { knowledge }\end{array}$ & $\begin{array}{l}\text { Cohen \& Levinthal } \\
\text { (1990); Nelson; } \\
\text { Winter (2005); } \\
\text { Casillas et al (2009); } \\
\text { Eriksson et al } \\
(2000) \text {; Zahra \& } \\
\text { George (2002); } \\
\text { Todorova \& Durisin } \\
(2007) \text {; Teece } \\
(2014)\end{array}$ \\
\hline & $\begin{array}{l}\text { Acquisition - } \\
\text { New } \\
\text { Knowledge for } \\
\text { Internationali- } \\
\text { zation }\end{array}$ & $\begin{array}{l}\text { Internal and } \\
\text { external } \\
\text { information } \\
\text { sources }\end{array}$ & $\begin{array}{l}\text { Casillas et al (2009); } \\
\text { Ericksson (2000); } \\
\text { Zahra \& George } \\
\text { (2002); Todorova \& } \\
\text { Durisin (2007); } \\
\text { March (1991) }\end{array}$ \\
\hline & $\begin{array}{l}\text { Assimilation, } \\
\text { transformation } \\
\text { and } \\
\text { exploitation of } \\
\text { knowledge for } \\
\text { Internationali- } \\
\text { zation }\end{array}$ & $\begin{array}{l}\text { Compatibility } \\
\text { between new } \\
\text { and previous } \\
\text { knowledge. } \\
\text { Capacity to } \\
\text { absorb new } \\
\text { knowledge }\end{array}$ & $\begin{array}{l}\text { Cohen \& Levinthal } \\
\text { (1990); Zahra \& } \\
\text { George (2002); } \\
\text { Casillas et al } \\
\text { (2009); Todorova } \\
\text { \& Durisin (2007); } \\
\text { Teece (2014) }\end{array}$ \\
\hline
\end{tabular}

Source: The authors.

The research strategy proposed is a simple case study. The case study is the best method for analysing the transformation of a firm, because only it allows analysing the various variables and

Revista de Negócios, v. 23, n. 1, p. 7-30, January, 2018. 
the dynamic involved (Child \& Smith, 1987; Yin, 2009) and for this reason it was the research strategy chosen by important studies in the field of international business (Johanson \& Vahlne, 1977; Mathews, 2006), which proves the relevance of the method.

In the qualitative study, the case to be analysed is defined intentionally to be able to understand a specific phenomenon, it is a "revelatory case" - that is, the information described is revealing. This situation occurs when the investigator has the opportunity to observe and analyse a previously not accessible scientific investigation (Yin, 2009; Merriam, 2002, 2009; Patton, 2015). "Outlier companies" are chosen, or situations where certain attributes are emphasized or revealed (Lervik, 2011).

For the selection of the unit studied in this research, the relevance of the company to the international process of Brazilian companies was considered. The size of the company was observed (the number of employees and assets); its level of transnationality, position in the ranking of the main international competitors in the sector; the availability of access to primary data, including key actors in the internationalization process, particularly members of the company's top administration, given the strategic character of the data collected.

Other factors considered were characteristics unique to the international process, such as late internationalization when compared with other private Brazilian groups or with other groups in global industry, despite the privileged position in the Brazilian market and the uncommon direction of the international process (up-ward).

Ramamurti (2009) explains that studies that involve research about "up-ward" investments those from developing countries to developed countries - are theoretically relevant because they go against the conventional wisdom about the direction in which capital, technology and knowledge should flow in the global economy. Studies of these cases constitute examples of situations that the traditional international business theory fail to explain well (Ramamurti, 2009; Madhok \& Keyhani, 2012).

The case studied in this research was that of the company Votorantim Cimentos, one of the largest players in the global cement industry - tenth position (GCR, 2016). It is the leader in the
Brazilian cement market and a member of Brazil's second largest private industrial group considering the value of net assets (Valor Econômico, 2013). It is among Brazil's emerging companies listed by Global Challenger 2016, from the Boston Consulting Group (BCG, 2016) and competes with companies that are among the 100 most internationalized in the world. The biggest companies in the cement industry in the world are the chinese firms (China Natinal Building Materials, Anhui Conch, Jidong), the Europeans (Lafarge-Holcim and Heidelberg Cement), as well the Mexican company Cemex.

The data collected from Votorantim appear in transcriptions of the interviews and field notes. They are based on broad questions or foci of interest, which became more direct and specific during the study. The abstractions were constructed from the data, in a bottom-to-top process.

Therefore, a rigid sequence of steps was not followed. The data collection and analysis were not conducted separately. The information collected were interpreted, which generated the need for new research for data, which is typical of qualitative research, which requires an integrated process of data collection and interpretation (Triviños, 1987; Taylor; Bogdan, 1988; Jones, 2004).

The data was collected from primary and secondary sources. A triangulation of the interviews was conducted with the secondary sources of data to maintain the integrity of the analysis (Miles \& Huberman, 1994). The primary data were collected by means of interviews and in documents, as suggested by Li (2007). Primary documents were collected at the company, such as internal reports and presentations and nonstructured interviews were conducted with directors of the organization being studied.

It was decided to use non-structured interviews because they provide the freedom and spontaneity needed by the informant, enriching the investigation, as indicated by Parkhe (2004) "in many areas of rigorous empirical investigation, there is simply no satisfactory substitute for interviews" (p. xviii). With the development of the study, semi-structured interviews were conducted, based on prepared questions, as indicated by Patton (2015). These were used above all to check previous affirmations of the same person or by other people interviewed, and to go more deeply

Revista de Negócios, v. 23, n. 1, p. 7-30, January, 2018. 
into specific issues.

The interviews, because of the strategic nature of the questions, were conducted with upper level executives of the organization or with people recognized for their considerable knowledge about the organization's internationalization process. Once the first interviews were initiated, the following ones were identified through "snowballing" (Patton, 2015).

Those interviewed included the Vice President of the Board of Directors of Grupo Votorantim, two directors of Votorantim Participações, a former president of Votorantim Cimentos, who was responsible for having initiated Votorantim's internationalization process and the first person from Votorantim Cimentos Brazil to be expatriated to Canada in the process of acquisition of the first production unit in that country.

The interviews were conducted in person and were recorded, which facilitated the data collection, because it guaranteed better fluency and total recovery of the information. The interviews totaled 16 hours of recordings.

In relation to the questions used in the interviews, it was requested that the people interviewed talk about the internationalization of the company, emphasizing its main moments. As the data collection and analysis advanced, the interviews became better organized, with a more specific focus on understanding the role of absorptive capacity for the internationalization process, as a way to validate information already received and to obtain additional information, complementing the dimensions that were not clear.

After the reading and rereading of each interview transcribed, they were codified (Strauss \& Corbin, 1998), and analytical tables were prepared to navigate through the data (Eisenhardt, 1989; Miles \& Huberman, 1994) with the assistance of the NVivo software.

Macro categories were developed and used as guides in the interviews and the data were chronologically organized. Within these macrocategories, smaller units of events were identified, for which reason the following steps were followed to analyse the data: a) reading of the interviews; b) codification of the interviews; c) reading and rereading of the codified interviews; d) grouping of the reports according to category; e) organization of the texts referring to each theme; f) analysis and interpretation of the results; g) preparation of the final text.

The NVivo software helped to organize the categories (called nodes) and establish the hierarchy according to the properties and dimensions. The categories listed by the literature can be filed, together with their concepts, which facilitates codification. Another advantage of the use of the software is that it allows agglutinating various portions of the interviews about the same category, which allows the easy creation of the analytical tables proposed by Miles and Huberman (1994).

\section{Analysis}

Votorantim Cimentos is a late mover in the global cement industry. Contrary to companies such as Holcim, Lafarge, Heidelberg Cement and Italcementi which internationalized from their base in developed countries (Switzerland, France, Germany and Italy), Votorantim is part of a group formed by companies in developing country, such as CEMEX and Argos. These companies are leaders in their markets of origin, which did not remain regional, expanding to other markets in developing countries by conducting operations known as up-market (Ramamurti, 2009). Therefore, they have a different starting point than companies from mature economies. They are in countries with medium income levels, that have institutional fragilities and have different patterns and paths of internationalization than multinationals from developed countries, thus configuring different internationalization processes.

The process is coherent with what generally takes place within the cement industry. Since they are in oligopolistic structures, they are companies that internationalize after they have command of the market in their countries and generate enough resources to be able to realize large investments abroad, given that the internationalization of this industry follows the foreign direct investment mode, or on a smaller scale, the formation of jointventures, or even the acquisition of shareholder participation. The exports tend to not have an important strategic significance. But, as Dunning et al (2008) emphasized, companies of the "third wave" of internationalization tend to use various mode of entrance.

The Votorantim group underwent an intense

Revista de Negócios, v. 23, n. 1, p. 7-30, January, 2018. 
process of diversification over five decades. Created in the 1930s, its internationalization only gained force in the first year of the twenty-first century, when it made foreign direct investments, thus committing a larger amount of resources in the international market.

Since 2001, Votorantim Cimentos has become a global consolidator (Ramamurti \& Singh, 2009). It expanded its activities internationally through acquisitions and came to compete for operational excellence in a mature industry, in both developing and developed countries, and indicated that it aspired to participate on the global stage (Lu \& Tung, 2007).

It is in an industry with consolidated technology, where scale and other cost advantages are essential. But, it had still not attained the scale and scope of internationalization of a large multinational in an advanced market, although it was among the ten largest players in the global cement industry.

The characterization of Votorantim is similar to the description that Lessard and Lucea (2009) made of CEMEX: "it is a 'middle out' company in two senses: it has expanded up-market and down-market from a country of medium income, medium technological development, median institutional development and much of its competitive advantage is in mid-level managerial processes, as characterized by Nonaka (1988) as a "middle out process" (pág 282).

To internationalize, the company had to absorb knowledge to active its goals. The Table 2 describes the main aspects related to the knowledge prior to internationalization of Votorantim Cimentos and the main categories identified as determinant. These features were prevalent before the first entry in the international market, that occurred in 2001, when the company bought an firm in North-America and began to produce there.

So, before the first acquisition abroad, the company had capacity to search for technological knowledge, what was essential to develop excellence in production process. The first generation of the owners (this is a family company) studied abroad and the company grew up in the Brazilian import substitution process. The Brazilian big market and the presence of foreign competitors created an experience in acquisitions but it was not sufficient to internationalize. In its own country, Votorantim developed a series of resources and capacities that have enabled it to achieve $40 \%$ of the Brazilian cement market. In Brazil, a country with a large continental dimension, with significant differences between regions (such as the differences between the operations in the South and Northeast), with the presence of relevant international competitors. In this regard, the environment of the country of origin constituted a context for the development of competencies for internationalization in the cement industry, despite the institutional voids of a Latin American country. The knowledge prior of first entry is summarized in table 2 .

But, new knowledge had to be acquired to internationalize. An obstacle to internationalization was the inexperience of managers about different cultures and an advantage was to be part of a business group, a guarantee to know about the global capital market.

Table 2. Knowledge Prior to the Internationalization of Votorantim Cimentos

\begin{tabular}{|c|c|}
\hline Categories & $\begin{array}{l}\text { Knowledge prior to the } \\
\text { internationalization }\end{array}$ \\
\hline $\begin{array}{l}\text { Role of the } \\
\text { Entrepreneur. } \\
\text { Boundary } \\
\text { spanner. } \\
\text { Search for } \\
\text { knowledge. }\end{array}$ & $\begin{array}{l}\text { Individual capacities that } \\
\text { stimulate the absorption of } \\
\text { technological development } \\
\text { generated by countries of the } \\
\text { center. Importation of machinery } \\
\text { and professionals. } \\
\text { Stock of Organizational } \\
\text { knowledge - memory - marked } \\
\text { by the need for technological } \\
\text { updating. } \\
\text { Recognition of the value of } \\
\text { knowledge acquired outside the } \\
\text { country. }\end{array}$ \\
\hline $\begin{array}{l}\text { Role of the } \\
\text { market }- \text { size } \\
\text { and growth } \\
\text { rate. Presence } \\
\text { of international } \\
\text { competitors. }\end{array}$ & $\begin{array}{l}\text { Capacity to conduct operations in } \\
\text { different regions of the country. } \\
\text { Ability in relationship with key } \\
\text { competitors. } \\
\text { The level of integration of } \\
\text { operation in Brazil was low. } \\
\text { Capacity that needed to be } \\
\text { developed before the first } \\
\text { entrance abroad. Knowledge of } \\
\text { management practices and } \\
\text { monitoring of strategic actions. }\end{array}$ \\
\hline $\begin{array}{l}\text { Experience } \\
\text { in } \\
\text { acquisitions } \\
\text { in the } \\
\text { domestic } \\
\text { market. }\end{array}$ & $\begin{array}{l}\text { Ability to identify and integrate } \\
\text { operations in acquisitions process } \\
\text { in the Brazilian market was not } \\
\text { sufficient to develop routines for } \\
\text { international acquisition. The } \\
\text { company recognized that had to } \\
\text { learn how to do that. }\end{array}$ \\
\hline
\end{tabular}




\begin{tabular}{|c|c|}
\hline $\begin{array}{l}\text { Capacity to develop } \\
\text { efficient production } \\
\text { process. }\end{array}$ & $\begin{array}{l}\text { Ability to absorb new technology, } \\
\text { combine resources and innovate } \\
\text { based on the point of view of the } \\
\text { organization process to reduce costs. } \\
\text { Excellence in operations. }\end{array}$ \\
\hline $\begin{array}{l}\text { Capacity for } \\
\text { the } \\
\text { development of } \\
\text { brands and } \\
\text { reputation. }\end{array}$ & $\begin{array}{l}\text { Strong brands and communication } \\
\text { strategies in Brazil. } \\
\text { Difficulty to transfer this capacity } \\
\text { given the particularities of the } \\
\text { market. }\end{array}$ \\
\hline $\begin{array}{l}\text { Capacity to access } \\
\text { global capital } \\
\text { market. }\end{array}$ & $\begin{array}{l}\text { Knowledge of global capital } \\
\text { market derived from the others } \\
\text { companies of Votorantim Group. } \\
\text { The role of the conglomerate. } \\
\text { Votorantim International and } \\
\text { other companies of the group. }\end{array}$ \\
\hline $\begin{array}{l}\text { Individual and } \\
\text { organizational } \\
\text { capacities } \\
\text { related to live } \\
\text { abroad. }\end{array}$ & $\begin{array}{l}\text { There was no education in } \\
\text { individual capacities or hiring of } \\
\text { professional with command of } \\
\text { other languages, or experience in } \\
\text { other countries. }\end{array}$ \\
\hline
\end{tabular}

Source: The authors.

Concerning the search for new knowledge, in Votorantim's internationalization process there was an emphasis on the role of crises in the development of capacities. As demonstrated by the literature, crises stimulate learning by threatening the existence of the organization (Winter, 2000) and lead to exploration, acquisition, and internalization of external knowledge (Zahra \& George, 2002; Kim, 2005; Volberda, Foss \& Lyles, 2010). Institutional changes that took place in Brazil in the early 1990s established a new economic reality that was more dynamic and competitive, which for Votorantim stimulated the "sensing" process (Teece, 2014) for the development of capacities to operate in the international market. The "rules of the game" (North, 1990) were changed, which came to require from the Votorantim group the capacity to "guarantee its participation in the global market", to confront a "sharper competition", conditions that required companies from the group "virtues, different from those required in the earlier phase, marked by the closing of the economy and pioneerism" (Caldeira, 2007, p.243).

Nevertheless, aspects of the internal environment were important in determining the recognition of value of knowledge about the internationalization process. A fragility of the strategic intentionality was identified in relation to internationalization, an aspect that did not receive attention in traditional international business theories, such as the theory of internalization (Buckley \& Casson, 1976), the eclectic paradigm
(Dunning, 1980) and vision based on knowledge (Kogut \& Zander, 1993), which ignored strategic intention, entrepreneurship and other managerial aspects of decision making. In the Votorantim case, the board was very reluctant to internationalize because the nationalist view that was part of the culture of the owners family. This caused an import delay in the internationalization process when compared with the competitors and others Brazilian companies.

For us, the worst tie, I think was this [Brazilian
closed economy, cost of capital very high] and
the maturity of the company and the
shareholders vision, in understanding that to
remain as an eminently Brazilian group in
businesses that are increasingly global (...)
tomorrow is a weakness [second worst ties to
internationalization]

When internationalization is part of the company's goals for growth, it shifts attention from the natural trend of incremental paths and encourages to take larger leaps, by considering long-term planning, which involves greater risks. For Huzschenreuter et al (2007), in the process of a search for opportunities (to seize, in the language of Teece, 2014), the values should involve something such as wanting "to be the first to move", or at least, to be among the first in this new wave, which did not occur in the case studied. The nationalist mental model developed in markets that had been closed for many years, an aspect identified within Votorantim's leadership, reinforced the belief that the domestic market was more important than the global arena. In this way, nationalist administrators tend to avoid internationalization as a strategic option, particularly in the case of direct foreign investment, a form of entrance that requires greater commitment of resources (Johanson \& Vahlne, 1977) and is difficult to reverse. Nadkarni and Perez (2007) found that the mental model for the domestic market influenced internationalization, but there is still only limited empiric evidence about the relationship between the mental model and the internationalization process (Nadkarni et al, 2011) and the case of Votorantim contributes to this line of research.

Other characteristics of the process of searching for knowledge during the internationalization of Votorantim Cimentos are highlighted in Table 3 . This search happened

Revista de Negócios, v. 23, n. 1, p. 7-30, January, 2018. 
before the first entry, too, but after the strategic intention to internationalize became stronger. This phase was a consequence of a trigger of activation but the company faced the lack of capacities and fragilities about structural organization and processes (lack of integration of units, inefficient communication channel, no sharing practices and no routines to search knowledge about foreign markets).

Table 3. Acquisition and Assimilation - Search for Knowledge in Votorantim Cimentos Internationalization Process

\begin{tabular}{|c|c|c|}
\hline Categories & \multicolumn{2}{|c|}{$\begin{array}{l}\text { Search for knowledge (acquisition) } \\
\text { during Votorantim Cimentos' } \\
\text { internationalization process }\end{array}$} \\
\hline $\begin{array}{l}\text { Role of crises } \\
\text { - triggers of } \\
\text { activation. }\end{array}$ & $\begin{array}{l}\text { Energy Crises; } \\
\text { CADE creation; } \\
\text { Recession (Collor } \\
\text { Plan) }\end{array}$ & $\begin{array}{l}\text { Reveal reactive } \\
\text { adaptive process }\end{array}$ \\
\hline $\begin{array}{l}\text { Recognition } \\
\text { of the value of } \\
\text { knowledge }\end{array}$ & $\begin{array}{l}\text { Weak strategic } \\
\text { intention }\end{array}$ & $\begin{array}{l}\text { Conflict. Search } \\
\text { for ideas consistent } \\
\text { with the previous } \\
\text { knowledge }\end{array}$ \\
\hline $\begin{array}{l}\text { Organizational } \\
\text { structure }\end{array}$ & $\begin{array}{l}\text { Poor integration } \\
\text { between corporate } \\
\text { units and among } \\
\text { units of VC. } \\
\text { Communication only } \\
\text { at the top }\end{array}$ & $\begin{array}{l}\text { Little stimuli to } \\
\text { sharing of } \\
\text { knowledge. } \\
\text { Lockout in terms } \\
\text { of } \\
\text { internationalization }\end{array}$ \\
\hline Diversity & $\begin{array}{l}\text { Low diversity of } \\
\text { work locations } \\
\text { among members of } \\
\text { the family owner, } \\
\text { and without } \\
\text { professionals with } \\
\text { experience with } \\
\text { other cultures }\end{array}$ & $\begin{array}{l}\text { Favors the low } \\
\text { recognition of value } \\
\text { of knowledge and } \\
\text { expanded barriers to } \\
\text { searching }\end{array}$ \\
\hline $\begin{array}{l}\text { Locus of } \\
\text { search for } \\
\text { knowledge }\end{array}$ & $\begin{array}{l}\text { Initially, by } \\
\text { bordering countries, } \\
\text { where there are } \\
\text { export operations }\end{array}$ & $\begin{array}{l}\text { Accumulative } \\
\text { knowledge. }\end{array}$ \\
\hline $\begin{array}{l}\text { Boundary- } \\
\text { spanner }\end{array}$ & $\begin{array}{l}\text { Executive with } \\
\text { international } \\
\text { experience in the } \\
\text { cement industry }\end{array}$ & $\begin{array}{l}\text { Access to tacit } \\
\text { knowledge, } \\
\text { experience }\end{array}$ \\
\hline $\begin{array}{l}\text { Formal } \\
\text { structure of } \\
\text { search for } \\
\text { knowledge }\end{array}$ & $\begin{array}{l}\text { Structure with the } \\
\text { objective of } \\
\text { prospecting } \\
\text { acquisition } \\
\text { opportunities }\end{array}$ & $\begin{array}{l}\text { Learning about the } \\
\text { market, } \\
\text { development of } \\
\text { methodology of } \\
\text { analysis }\end{array}$ \\
\hline $\begin{array}{l}\text { Types of } \\
\text { knowledge }\end{array}$ & $\begin{array}{l}\text { About the country } \\
\text { growth, institutional } \\
\text { conditions), compani } \\
\text { acquisition, search fo }\end{array}$ & $\begin{array}{l}\text { (opportunities for } \\
\text { questions, logistical } \\
\text { es that are targets for } \\
\text { r clusters }\end{array}$ \\
\hline
\end{tabular}

\begin{tabular}{|l|l|l|}
\hline $\begin{array}{l}\text { Sources of } \\
\text { knowledge }\end{array}$ & $\begin{array}{l}\text { Travels, visits to } \\
\text { factories abroad, } \\
\text { documents of } \\
\text { companies, outside } \\
\text { consulting, case } \\
\text { studies }\end{array}$ & \\
\hline
\end{tabular}

Source: The authors.

During the knowledge acquisition process, the action of a boundary-spanner was found to be relevant. An executive participated who had international experience as CEO of cement companies and who brought a diversity of perspectives and experiences, which allowed a gain of intensity, velocity and legitimacy to the process of searching for knowledge for internationalization. As the findings of this study suggest, the existence of people with international experience in other companies can bring significant gains by expanding the capacity to absorb new knowledge about internationalization, because they expand the locus of the search and decrease the chances that the company fall into traps of familiarity, maturity and or affinity and they facilitate the assimilation process because the new knowledge can be 'translated'. The access to these "experiences" took place via interorganizational relationships, which shows the capacity of knowledge to be generated both by relations within the company and those with other companies.

During the learning process about internationalization was identified the need to realize structural changes in the organization based on the domestic market. Greater integration was conducted among the regions, processes that involved an expressive transfer of knowledge between units and generated the transformation of tacit knowledge developed by a region into codified knowledge, which could be transferred to others. A team of replicators was also formed. These experiences were, therefore, fundamental for internationalization, despite the greater complexity needed to conduct this transference in the international market, as the interviews revealed.

In relation to the mode of entrance, Votorantim Cimentos followed a standard established in the sector, marked by an intense process of mergers and acquisitions, either partial or total. Once the entrance in the international market began, with the first acquisition, Votorantim Cimentos created VCNA - 
Votorantim Cement North America and strengthened the vision that it could grow in the market, that it had competence to do so and could practice price levels and leveraging like the large multinationals. But, they identified that they had to learn to operate in markets very different from the Brazilian market. The data revealed that it was a process of trial and error.

One example of routines that had to be developed was the distribution systems for the product, which required abilities not developed in the domestic market. They identified obstacles referring to cultural differences and difficulties in the process of knowledge transfer and they had to modify the Votorantim Cimentos Management System. An outside consulting firm was a source of knowledge for the integration process of the new subsidiary and for the initial operating studies, above all concerning the specific legislation of the country and the environmental issues and expatriates were qualified to transfer, especially, the production management knowledge.

The management system developed in Brazil proved to be very complex to be transferred to other realities, at the subsidiaries. When the integration process advanced, they saw peculiar characteristics of the mode of operation of each country. Furthermore, it was during the international management process that Votorantim Cimentos learned to get along with worker unions. Abilities in the relationship with workers also had to be developed and adapted to the local culture.

As far as the new subsidiaries were incorporated, new management tools were developed with standards of operational efficiency. A tool called optimal structural cost was created.

The acquisition, therefore, represented both exploitation - use of the base of knowledge, with a refinement of routines, as well as exploration which allowed the firm to renovate its knowledge base (March, 1991). Each time that the knowledge base was applied, opinions about what functioned and why it functioned, were more firmly established in the minds of the administrators, and thus, the new routines were established (Nelson \& Winter, 2005).

The analysis of the first outside acquisition of a productive unit showed that the knowledge that is not useful for a given reality begins to disappear from the organizational memory. Step by step, the exploitation, as well as a fine-tuning based on the development of the internationalization process, reduced the variety of the firm's knowledge base and promoted ossification and simplicity. Acquisitions, as Vermeulen and Barkema (2001) showed, contrary to greenfields, make firms more tolerant in the sense that new ways of doing things are identified, which can be found in the case studied. The new circumstances of acquisition, in new territory, brought new information and incentives that triggered the search for and creation of new knowledge.

At the same time that the company identified the need to have a homogeneous global platform for management of operational processes and indicators, it was determined to be important to consider regional characteristics. This denotes the development of the ability to have flexibility during the internationalization process. When new routines were being established, contributing to greater rigidity, internationalization brought an infusion of new ideas and new ways of doing things.

Although the creation of routines was necessary and resulted of a learning process, it also had undesirable effects (Hannan \& Freeman, 1984), which need to be transported for a better adjustment to new conditions.

Table 4 presents the main aspects related to the processes of transformation and exploitation of knowledge during the internationalization of Votorantim Cimentos.

Table 4. Transformation and Exploitation of Knowledge in Votorantim Cimentos Internationalization Process

\begin{tabular}{|c|c|}
\hline Categories & Transformation and exploitation \\
\hline $\begin{array}{l}\text { Development of } \\
\text { new abilities }\end{array}$ & $\begin{array}{l}\text { Abroad conditions were unknown } \\
\text { (management system emphasized the } \\
\text { short term instead of long term; } \\
\text { perception of the employee about } \\
\text { Brazilians ("Brazilian Indian"); profile } \\
\text { of the employees; relationship with } \\
\text { unions and found required new abilities } \\
\text { - and these conditions demanded the } \\
\text { existence of new routines } \\
\text { "This process was slower than we } \\
\text { imagined", said an interviewee }\end{array}$ \\
\hline $\begin{array}{l}\text { Creation of } \\
\text { routines }\end{array}$ & $\begin{array}{l}\text { Adaptation of the VCPS system } \\
\text { Votorantim Cements Production System } \\
\text { Outside consulting and expatriation } \\
\text { were participants }\end{array}$ \\
\hline
\end{tabular}




\begin{tabular}{|l|l|}
\hline New & $\begin{array}{l}\text { Excellent structural cost }- \text { technique } \\
\text { created during the internationalization } \\
\text { technologies for } \\
\text { process. Designed for comparison } \\
\text { between units and represents the } \\
\text { management on } \\
\text { integration of } \\
\text { subsidiaries }\end{array}$ \\
$\begin{array}{l}\text { continuity in the creation of the new } \\
\text { knowledge process }\end{array}$
\end{tabular}

Source: The authors.

\section{Conclusion}

The multinational studied internationalized to exploit advantages of ownership developed in the domestic market. These advantages include intangible assets, such as managerial ability and greater operational efficiency. Therefore, depending on the context in which the internationalization takes place (the industry), capacities can be developed in the emerging countries, which will have to transfer knowledge to subsidiaries in foreign countries, a capacity that is still being developed given the immaturity of the international process among companies from the periphery. In the case in study, this immaturity takes place in terms of internationalization because it is a mature company, well established in the market of origin and that had to make an intense effort to learn to act globally.

This case study revealed aspects of the organization's domestic environment that affected its strategic decisions referring to internationalization. The following aspects that affected internationalization stood out: its formation in a conglomerate, governance structure and the low coordination between the regions of the company.

The participation in a conglomerate, typical of companies in developing countries, which supported themselves in this configuration to fillin institutional gaps, at the same time that it drained resources from the productive activity in question (cement, in this case) to conduct other activities, did not stimulate production abroad; in other moments, it favored the internationalization of the cement company through cultivation of access to the international capital market and the sharing of practices. Nevertheless, the interviews revealed a low coordination between the business units during the organizational history, which expanded over time.

The governance structure described revealed signs of an organization that was poorly adapted to a market that had become unstable. The interviews showed an organization with centralized decision making and with conflicts between ownership and management, particularly concerning internationalization, which increased the time of searching for knowledge about the foreign market. The influence of a nationalist mental model was identified, in which the domestic market was perceived as a priority. Under this aspect, managerial discretion is also considered in the internationalization processes. The development of capacities are not separated from the strategy and depend on the "nature of the managerial orchestration" (TEECE, 2014).

The administrative structure of the case studied limited coordination between its units that are spread among many regions of the country, which made it difficult to establish synergies and develop a single sense of direction and strategic thinking and above all, to share best practices, and create knowledge - capacities that are fundamental to action in the global market.

Based on this contextual configuration, the company sought to develop capacities for internationalization, driven by an entrepreneurial attitude of the company administrators. The first finding was that having operational efficiency was not sufficient, operating abroad would require dynamic capacities, based on the development of new routines and processes inherent to internationalization. An acquisition process of knowledge should be developed. The administrators perceived that the company needed to learn to be global, or, in other words, needed "knowledge about internationalization". It was in this recognition of the value of knowledge about internationalization that an intense process began to search for new knowledge, despite the fear and uncertainty that this strategic intention represented.

In this sense, it was observed that the experience developed until that time in years of exporting was not sufficient to prepare the company for production abroad. It was necessary to develop a structure with routines suitable for the acquisition and prospecting of knowledge. This process involved both internal sources, which sought knowledge abroad through travel and visits to possible acquisition targets; as well as external sources, such as consulting companies that conduct studies of best practices in

Revista de Negócios, v. 23, n. 1, p. 7-30, January, 2018. 
internationalization models. This search process revealed a scarcity not only of organizational knowledge, but also of individual knowledge, given that there was no one on staff with abilities inherent to experience with other cultures.

The effective entrance into the international market revealed a still unknown reality, which corroborated the literature by identifying internationalization as a source of learning. Differences were identified in the market practices from various aspects - realization of investments, labor and union relations, relations among employees and managers and in work organization. There was a transfer of the Brazilian managerial system abroad, but it proved to be incapable of being implemented as it was in Brazil, given the peculiarities of the foreign reality. Therefore, a new phase of generation of knowledge was developed, which represented both exploitation - the use of the knowledge base, with a refinement of routines, as well as exploration - the renovation of the base of knowledge.

\section{Implications and Further Research}

The description of the role that knowledge exercised in the internationalization process in the case presented contributed to the literature by showing how the creation of capacities and their exploitation are enrooted in specific contextual conditions. The study contributed by showing how and why an emerging company was able to create capacities in an emerging country and expand them through an internationalization process to become a global consolidator.

The main limitation of this study refers to the method and data sources used. Despite the internationalization process being conducted by senior management, the data are limited to the view of the main drivers of the process. Similarly, when using secondary data provided by the organization, other sources of data that could assist in the process of understanding are discarded.

The authors suggest that further research explores the relation of internationalization and absorptive capacity using the categories found in this study with a quantitative method by the way of analyse others sectors in an emerging market.

\section{References}

Apriliyanti, I; D.; Alon, I. (2017) Bibliometric analysis of absorptive capacity. International Business Review, 26, 896-907.

Argote, L. (1999) Organizational Learning: Creating, Retaining \& Transferring Knowledge. Klumer Academic Publisher, 1999.

Barkema, H. Vermeulen, F. (1998). International Expansion through Start up or Acquisition: A Learning Perspective. The Academy of Management Journal. Vol. 41, No. 1 (Feb., 1998), pp. 7-26

Barney, J. B., (1991) Firm resources and sustained competitive advantage. Journal of Management, 17, 99-120.

BCG - Boston Consulting Group (2016). Global Leaders, challengers and champions:The engines of emerging markets. Retrieved from www.bcgperspectives.com/images

Becker, M.; Lazaric, N.; Nelson, R. \& Winter, S. (2005) Applying organizational routines in understanding organizational change. Industrial and Corporate Change, v.14, n.5, p. 775-791.

Becker-Ritterspach F. \& Bruche, G. (2012) Capability creation and internationalization with business group embeddedness - the case of Tata Motors in passenger cars. European Management Journal. vol:30 iss:3, 232-247. doi:10.1016/j.emj.2012.03.009

Bingham, C.; Eisenhardt, K. (2011). Rational heuristics: the 'simple rules' that strategists learn from process experience. Strategic Management Journal. Vol 32, 13, Pages 1437-1464.

Bilgili, T.; Kedia, B. \& Bilgili, H. (2016) Exploring the influence of resource environments on absorptive capacity development: The case of emerging market firms. Journal of World Business. $\quad 51, \quad 700-712 . \quad$ doi 10.1016/j.jwb.2016.07.008

Blazejewski, S. (2011) When truth is the daughter of time: the longitudinal case studies in international business research. In Piekkari, R.;

Revista de Negócios, v. 23, n. 1, p. 7-30, January, 2018. 
Welch, C. (2011) Rethinking the Case Study in International Business and Management Research. USA: Edward Elgar Publishing Limited.

Blomstermo, A.; Eriksson, K.; Lindstrand, A. \& Sharma, D. (2004). The perceived usefulness of network experiential knowledge in the internationalizing firm. Journal of International Management, vol. 10, issue 3, 355-373.

Buckley, P.J.; Clegg, L.; Cross, A.R.; Liu, X.; Voss, H. \& Zhen, P. (2007) The determinants of Chinese outward foreign direct investment. Journal of International Business Studies. 38 (4):499-518.

Buckley, P. \& Park, B. (2014) Realised absorptive capacity, technology acquisition and performance in international collaborative formations; an empirical examination in the Korean context. Asia Pacific Business Review, vol 20, n.1, 109-135. doi;10.1080/13602381.2013.779126.

Buckley, P. J; Doh, J. P \& Benischke, M. Towards a renaissance in international business research? Big questions, grand challenges, and the future of IB scholarship. Journal of International Business Studies, 48, 1045-1064.

Burgelman, R. (2011) Bridging History and Reductionism: A Key Role for Longitudinal Qualitative Research. Journal of International Business Studies. Vol. 42, Issue 5, Pages 591-601

Casson, M.C. (1976) The future of multinational enterprise, London: Homes \& Meier.

Caldeira, J. (2007). Votorantim 90 anos: uma história de trabalho e superação. São Paulo: Mameluco.

Camisón, C. \& Forés, B. (2010). Knowledge absorptive capacity: New insights for its conceptualization and measurement. Journal of Business Research, v.63, p. 707-715. doi:10.1016/j.jbusres.2009.04.022

Casillas, J., Moreno, A., Acedo, F., Gallego, M. \& Ramos, E. (2009). An integrative model of the role of knowledge in the internationalization process. Journal of World Business, 44, 311-322. doi:10.1016/j.jwb.2008.08.001

Chandler, A. (1962). Strategy and Structure. Cambridge. Mass.:MIT Press.

Chen, Y,; Lin, M. \& Chang, C. (2009) The positive effects of relationship learning and absorptive capacity on innovation performance and competitive advantage in industrial markets. Industrial Marketing Management, 38 (2), 152158.

Child, J. (1972). Organizational Structure, Environment and Performance: the role of strategic choice. Sociology, v.6, p 2-22.

Child, J. \& Smith, C. (1987) The Context and Process of organizational transformation. Cadbury Limited in its Sector. Journal of Management Studies, v.24, n.6., p.565-593.

Cohen, W. \& Levinthal, D. (1989). Innovation and Learning: The Two Faces of R\&D. Economic Journal, 99, 569-596. doi: 10.2307/2233763

Cohen, W. \& Levinthal, D. (1990) Absorptive capacity: a new perspective on learning and innovation. Administrative Science Quartely, vol. 35, n. 1, Special issue: Technology, Organizations and Innovation. March, 128-152. doi: $10.2307 / 2393553$

Colantuono, A. \& Pinho, M. (2012) Internacionalização de empresas produtoras de cimento: análise da Votorantim Cimentos. III Congresso Latino-Americano de Historia Económica y XXIII Jornadas de Historia Económica. Retrieved from www.aahe.fahce.unlp.edu.ar/Jornadas/iii-cladhexxiii-jhe

Coutinho, L.; Hiratuka, C \& Sabatini, R. (2008). O investimento direto no exterior como alavanca dinamizadora da economia brasileira. In: Barros, O; Giambiagi, F. (org.) (2008). Brasil Globalizado: o Brasil em um mundo surpreendente. Rio de Janeiro: Elsevier.

Cuervo-Cazurra, A. (2012). Extending theory by analysing developing country multinational companies: solving the goldilocks debate. Global Strategy Journal. V.2, 153-167.

Revista de Negócios, v. 23, n. 1, p. 7-30, January, 2018. 
doi: 10.1111/j.2042-5805.2012.01039.x

Cuervo-Cazurra, A. \& Genc, M. (2008). Transforming disadvantage into advantage: developing-country MNEs in the least developed countries. Journal of International Business $\begin{array}{llll}\text { Studies. } & 39 & \text { (6), } & \text { 709-725. }\end{array}$ doi:10.1057/palgrave.jibs. 8400390 .

Cuervo-Cazurra, A. (2016). Multilatinas as sources of new research insights: the learning and escape drivers of international expansion. Journal of Business Research, vol 69, issue 6, 1963-1972. doi:10.1016/j.jbusres.2015.10.142

Cuervo-Cazurra, A. \& Rui, Huaichuan. (2017) Barriers to absorptive capacity in emerging market firms. Journal of World Business, 52, 727-742.

Denzin, N. K. \& Lincoln, Y. S. Handbook of qualitative research. Londres: Sage, 1994.

Dunning, J. H. (1980). Towards an eclectic theory of international production: some empirical tests. Journal of International Business Studies, 11(1), 9-31. doi:10.1057/palgrave.jibs.8490593

Dunning, J., Kim, C. \& Park, D. (2008). Old Wine in new bottles: a comparison of emerging-market TNCs today and developed-country TNCs thirty years ago. In Sauvant, K. (org) The Rise of Transnational Corporations from Emerging Markets. Threat or Opportunity? Edward Elgar Publishing, USA.

Easterby-Smith,M., Graça, M., Antonacopoulou, E. \& Ferdinand, J. (2008) Absorptive Capacity: a process perspective. Management Learning. 39 (5), 483-501. doi: 10.1177/1350507608096037

Eisenhardt, K., (1989) Building Theories from Case Study Research. Academy of Management Review, vol. 14, n.4, 532-550. doi: 10.5465/AMR.1989.4308385

Eriksson, K.; Majkgard, A. \& Sharma, D. (2000). Path Dependence and knowledge development in the internationalization process. Management International Review, 40, págs 307-328.

Eriksson, K.; Johanson, J.; Majkgard, A. \& Sharma, D. (2009). Experiential knowledge and cost in the internationalization process. Journal of International Business Studies, 28 (2), págs 337 360.

Forsgren, M. The concept of learning in the Uppsala internationalization process model: a critical review. International Business Review, 11(3), 257-277.

Foss, N. J., Lyles, H. W. \& Volberda, M.A. (2010). Absorbing the concept of absorptive capacity: how to realize its potential in the organization field. Organization Science, v.21, n. 4, p. 931-951. http://dx.doi.org/10.2139/ssrn.1513184

Flatten, T.C., Engelen, A., Zahra, S.A. \& Brettel, M. (2011). A measure of absorptive capacity: scale development and validation. European Management Journal, v.29, n. 2, p. 98-116. doi:10.1016/j.emj.2010.11.002

Fleury, A. \& Fleury, M. T. Brazilian Multinationals. Cambridge University Press, 2011.

Furquim, N. \& Meireles, D. (2006) Grupo Votorantim: Um caso contemporâneo de internacionalização bem-sucedida. Internext, (1), 1, 1-22.

Garrido, I. L.; Parente, R. C,; Gonçalo, C. R. \& Vasconcellos, S. L. (2017) Mantendo-se Inovadoras: O papel do Desempenho Passado, da Capacidade Absortiva e da Internacionalização. Brazilian Business Review, 14 (6), p. 559-574. DOI: http://dx.doi.org/10.15728/bbr.2017.14.6.1

Gioia, D, Corley, K. \& Hamilton, A. (2012). Seeking qualitative rigor in inductive research: notes on the Gioia Methodology. Organizational Research Methods. 16 (1), 15-31. doi: $10.1177 / 1094428112452151$

GCR, Global Cement Report (2016). Top 100 Report. Retrieved from www.globalcement.com/reports

Guillén, M. \& Garcia-Canal, E. (2009) The American Model of the Multinational Firm and the New Multinationals from Emerging Economies. Academy of Management Perspectives, may. 2335. doi: 10.5465/AMP.2009.39985538

Revista de Negócios, v. 23, n. 1, p. 7-30, January, 2018. 
Hannan, M. T., \& Freeman, J.. (1984). Structural Inertia and Organizational Change. American Sociological Review, 49(2), 149-164. Retrieved from http://www.jstor.org/stable/2095567

Hernandez, E; Guillén, M. (2018) What's theoretically novel about emerging-market multinationals? Journal of International Business Studies, 49, 24-33. doi.org/10.1057/s41267-0170131-7

Hutzschenreuter, T., Pedersen, T. \& Volberda, H. (2007) The role of path dependence and managerial intencionality: a perspective on international business research. Journal of International Business Studies, 38 (7), 1055-1068. doi:10.1057/palgrave.jibs. 8400326

Jansen, J.J.P., Van Den Bosch, F.A.J. \& Volberda, H.W. (2005) Managing potential and realized absorptive capacity: how do organizational antecedents matter? Academy of Management Journal, v.48, n. $6, \quad 999-1015$. doi:10.1057/palgrave.jibs. 8400326

Jiménez-Barrionuevo, M. M., García-Morales, V. J., \& Molina, L. M. (2011). Validation of an instrument to measure absorptive capacity. Technovation. 31(5/6), 190-202. doi: 10.1016/j.technovation.2010.12.002

Jones, V. The Rhythms of Latin America: a context and guide for qualitative research.In Marschan-Piekkaru, R \& Welch, C. (2004). Handbook of qualitative research methods for international business. UK: Edward Elgar Publishing Limited, 2004.

Johanson, J. \& Vahlne, J. (1977) The Internationalization Process of the Firm - A model of Knowledge Development and Increasing Foreign Market Commitments. Journal of International Business Studies, 8 (1):23-32. doi:10.1057/palgrave.jibs. 8490676

Johanson, J. \& Vahlne,J E. (2006) Commitment and opportunity development in the internationalization process: A note on the Uppsala internationalization process model. MANAGE. INT. REV. (2006) 46: 165. https://doi.org/10.1007/s11575-006-0043-4
Johanson, J. \& Vahlne, JE (1997) The internationalization process of the firm-a model of knowledge development and increasing foreign market commitments. Journal of International Studies., 8 (1), pp. 23-32

Kale, P.; Dyer, J. H. \& Singh, H. (2002).Alliance capability, stock market response, and long-term alliance success: the role of the alliance function. Strategic Management Journal 23(8): 747-767.

Kim, L. (2005) Da Imitação à Inovação: a dinâmica do aprendizado tecnológico da Coreia. Campinas, SP: Editora da UNICAMP.

Knight, G. A., \& Liesch, P. W. (2002). Information internalization in internationalizing the firm. Journal of Business Research, 51(12): 115.

Kogut, B. \& Zander, U. (1993). Knowledge of the firm and the evolutionary theory of the multinational corporation. Journal of International Business Studies, fourth quarter, 625- 645. doi:10.1057/palgrave.jibs. 8400058

Lall, S. (1983) The new Multinationals: The Spread of the Third World Enterprises. Chichester, UK: John Wiley \& Sons.

Lane, P., Koka, B. \& Pathak, S. (2006). The Reification of Absorptive Capacity: a critical review and rejuvenation of the construct. Academy of Management Review, vol.31., n.4, 833-863. doi: 10.5465/AMR.2006.22527456

Lervik, J. (2011). The single MNC as research site. In Perkkari, R.; Welch, C. Rethinking the case study in international business and management research. UK: Edward Elgar.

Lessard, D. \& Lucea, R. (2009). Mexican multinationals: Insights from CEMEX. In Ramamurti, R. \& Singh, J. Emerging Multinationals in Emerging Markets. NY: Cambridge University Press.

Li, P. (2007). Toward an integrated theory of multinational evolution: the evidence of Chinese multinational enterprises as latecomers. Journal of International Management, 13 (3), 296-318. doi:10.1016/j.intman.2007.05.004

Revista de Negócios, v. 23, n. 1, p. 7-30, January, 2018. 
Luo, Y. \& Tung, R. (2007) International expansion of emerging market enterprises: a springborard perspective. Journal of International Business Studies, 38 , 481-498. doi:10.1057/palgrave.jibs. 8400275

Luo, Y \& Tung, R. (2018) A general theory fo springboard MNEs. Journal of International Business Studies, 49, 129-152. doi 10.1057/s41267-017-0114-8

March, J. (1991) Exploration and Exploitation in organizational learning. Organization Science, 2, 71-87. http://dx.doi.org/10.1287/orsc.2.1.71

Marschan-Piekkaru, R \& Welch, C. (2012) Reflections on Using Qualitative Research Methods in International Business. Retrieved from www.ita.hse.fi/2006/4/ita_2006_04_a7.pdf.

Mathews, J. (2006) Dragon Multinationals: New Players in the 21 st century globalization. Asia Pacific Journal Management, 23, 5-27. doi 10.1007/s10490-006-6113-0

Mathews, J. \& Cho, D. (1999) Combinative Capabilities and Organizational Learning in Latecomer Firms: the case of the Korean Semiconductor Industry. Journal of World Business, 34 (2), 1999, pp. 139-156. doi:10.1016/S1090-9516(99)00013-9

Madhok, A. \& Keyhani, M. (2012). Acquisitions as entrepreneurship: asymmetries, opportunities, and the internationalization of multinationals from emerging economies. Global Strategy Journal., 2: 26-40. DOI: $10.1002 / g s j .1023$

Melin, L. (1992). Internationalization as a strategy process. Strategic Management Journal, 13, Winter, special issue, p. 99-118.

Merriam, S. (2002) Introduction to qualitative research, Jossey-Bass.

Merriam, S, (2009) Qualitative research: a guide to design implementation, John Wiley \& Sons.

Meyer, K. E. \& Peng, M. (2016) Theoretical foundations of emerging economy business research. Journal of International Business Studies, 47, 3-22. doi: 10.1057/jibs.2015.34
Miller, D. \& Friesing, P. H. (1982) The longitudinal analyses of organizations: a methodological perspective. Management Science, v. 28, n. 9, p. 1013-1033. doi: $10.1002 / g s j .1023$

Milles, M. \& Huberman, A. (1984). Qualitative data analysis: a source book of new methods. Bervely Hills: Sage.

Nadkarni S. \& Perez, P. (2007). Prior conditions and degree of internationalization: the mediating role of domestic mindsets. Journal of International Business Studies 38 (1), 160- 176. doi:10.1057/palgrave.jibs. 8400248

Nadkarni, S., Herrmann, P. \& Perez, P. (2011). Domestic Mindsets and Early International Performance: the moderating effect of global industry conditions. Strategic Management Journal, 32, 510-532. DOI: 10.1002/smj.888

Nelson, R. \& Winter, S. (2005). Uma teoria evolucionária da mudança econômica. Campinas, SP: Editora da UNICAMP.

Nonaka, I. (1988) Toward Middle-up-down Management: Accelerating Information Creation. Sloan Management Review, Spring. Retrieved from http://sloanreview.mit.edu/article/towardmiddleupdown-management-acceleratinginformation-creation/

Nonaka, I.; Takeuchi, H. (1997) Criação de Conhecimento na Empresa: Como as Empresas Japonesas Geram a Dinâmica da Inovação. Rio de Janeiro: Campus.

North, D., (1990) Institutions, Institutional Change and Economic Performance, Cambridge: Cambridge University Press.

Parkhe, A. (2004). Interviews: a key data source in international business research. In MarschanPiekkaru, R \& Welch, C. Handbook of qualitative research methods for international business. UK: Edward Elgar Publishing Limited.

Patton, M. Q. (2015). Qualitative Research \& Evaluation Methods: integrating theory and

Revista de Negócios, v. 23, n. 1, p. 7-30, January, 2018. 
practice, 4th ed. Thousand Oaks, CA and London: Sage.

Pettigrew, a. (2012). Context and Action in the Transformation of the firm: a reprise. Journal of Management Studies, vol 49, issue 7, pp 01-25.

Penrose, E. (1957) Limits to the Growth and Size of Firms. American Economic Review, vol 45, n.2, p. 531-43.

Ramamurti, R. (2009) Why study emergingmarket multionationals? In RAMAMURTI, R,; SINGH, J. Emerging Multinationals in Emerging Markets. NY: Cambridge University Press.

Ramamurti, R. \& Singh, J. (2009). Indian multinationals: generic internationalization. In Ramamurti, R, \& Singh, J. Emerging Multinationals in Emerging Markets. NY: Cambridge University Press.

Ramamurti, R. (2012). What is really different about emerging market multinationals? Global Strategy Journal, v.2, 41-47. DOI: $10.1002 /$ gsj.1025

Rugman, A. (2008) How global are TNCs from emerging markets? In Sauvant, K. (org) The Rise of Transnational Corporations from Emerging Markets. Threat or Opportunity? Edward Elgar Publishing, USA.

Santos, L. B. (2008) Reestruturação, internacionalização e novos territories de acumulação do Grupo Votorantim. Dissertação. Universidade Estadual Paulista, Faculdade de Ciências da Tecnologia.

Sapienza, H.; Autio, E; George, G \& Zahra, S. A. (2006) Capability perspective on the effects of early internationalization on firm survival and growth. Academy of Management Review, 31, p. 914-933.

Strauss, A. \& Corbin, J. (1998) Basics of Qualitative Research, Sage Publications.

Szulanski, G. (1996). Exploring internal stickiness: impediments to the transfer of best practices within the firm. Strategic Management Journal, v.17, n. 10, p. 27-43.
DOI: $10.1002 / \mathrm{smj} .4250171105$

Taylor, S. \& Bogdan, R. (1998) Introduction to Qualitative Research Methods: a guidebook and resource. NY: John Wiley\&Sons, Inc.

Teece, D. J. (1986) Profiting from technological innovation: implications for integration, collaboration, licensing and public policy. Research Policy, 15, 285-305. doi:10.1016/00487333(86)90027-2

Teece, D. J. (2007) Explicating Dynamics Capabilities: the nature and microfoundations of (sustainable) enterprise performance. Strategic Management Journal, 28, 1319- 1350. DOI: $10.1002 /$ smj.640

Teece, D. J. (2014) A dynamics capabilities-based entrepreneurial theory of the multinational enterprise. Journal of International Business Studies, 45, 8-37. doi:10.1057/jibs.2013.54

Todorova, G. \& Durisin, B. (2007) Absorptive Capacity: valuing a reconceptualization. Academy of Management Review, vol. 32, 2007, p. 774-786. doi: 10.5465/AMR.2007.25275513

Triviños, A. (1987) Introdução à pesquisa qualitativa em ciências sociais: a pesquisa qualitativa em educação. São Paulo: Atlas.

Tsai, w. (2001). Knowledge transfer in intraorganizational networks: Effects of network position and absorptive capacity on business unit innovation and performance. Academy of Management Journal, 44 (5), 996-1004.

UNCTADStat - United Nations Conference on Trade and Development (2016). Retrieved from unctad.unctad.org/wds/TableViewer/tableView.as px

Valor Econômico, (2013). 200 Maiores Grandes Grupos. Ano 12, n.12, Dezembro.

Van de Ven, A; Huber, G. (1990). Longitudinal Field Research Methods: Studying Processes of Organizational Change. Administrative Science Quartely 1 (3):213-219.

Van Maanen, J. (1983) Qualitative methodology.

Revista de Negócios, v. 23, n. 1, p. 7-30, January, 2018. 
BH; Sage.

Vermeulen, F. \& Barkema, H. (2002). Pace, Rhythm and Scope: Process dependence in building a profitable multinational corporation. Strategic Management Journal. 23:637-653. DOI: $10.1002 / \mathrm{smj} .243$

Volberda, H.; Foss, N. \& Lyles, M. (2010) Absorbing the Concept of Absorptive Capacity: How to Realize Its Potential in the Organization Field. Organization Science. V. 21,p.931-951.

Votorantim (2017). Relatório 2017. Retrieved from https://mzfilemanager.s3.amazonaws.com/8b9699e2-23e0419e-9df2-0c87f04b3208/relatoriosanuais/a562a1cd783fa5fa9ce0eed758e78505370b 9fb16e0f722095e1bf4aa56a7bf9/relatorio_votora ntim_2017.pdf

Wells, L. (1983). Third World Multinationals: The Rise of Foreign Investment from Developing Countries. Cambridge, MA: the MIT Press.

Wells, L. (2009) The Third World multinationals: a look back. In Ramamurti, R. \& Singh, J. Emerging Multinationals in Emerging Markets. UK: Cambridge University Press.

Wilkins, M. (2010). The History of the multinational enterprise. In. RUGMAN, A.; The Oxford Handbook of International Business. 2nd edition. UK: Oxford University Press.

Winter, S. G.. (2000). The Satisficing Principle in Capability Learning. Strategic Management Journal, 21(10/11), 981-996. Retrieved from http://www.jstor.org/stable/3094423

Wu, A. \& Voss, H. (2015) When does absorptive capacity matter for international performance of firms? Evidence from China. International Business Review 24, 344-351. http://dx.doi.org/10.1016/j.ibusrev.2014.08.006

Yin, R. (2009) Case Study Research: Design and Methods, 4th ed., Thousand Oaks: Sage.

Zahra, S. \& George, G. (2002). Absorptive Capacity: a review, reconceptualization, and extension. Academy of Management Review, vol.27, n.2, 185-203. doi: 10.5465/AMR.2002.6587995

Zollo, M. \& Winter, S. G. (2002) Deliberate Learning and the Evolution of Dynamic Capabilities. Organization Science, v. 13, n. 3, p. 339-351.

Revista de Negócios, v. 23, n. 1, p. 7-30, January, 2018. 